\title{
Cytotoxic and genotoxic effects of the ent-kaurenoic acid and $e n t$ - kaurenoic acid enriched Mikania glomerata extract in V79
}

\author{
NATÁLIA HELEN FERREIRA, ARTHUR BARCELOS RIBEIRO, MARIÂNGELA DIAS DE MORAIS, \\ ALINE DE MORAIS PEIXOTO, MARCELA ARAÚJO BERNARDINO, MONIQUE RODRIGUES \\ MOREIRA, ANA CAROLINA FERREIRA SOARES, VLADIMIR CONSTANTINO GOMES HELENO, \\ RODRIGO CASSIO SOLA VENEZIANI, DENISE CRISPIM TAVARES ${ }^{\vee}$ \\ Universidade de Franca. Avenida Dr. Armando Salles de Oliveira, 201, 14404-600, Franca, São Paulo, Brazil. \\ Tel.: +55-16-3711-8871, Fax: +55-16-3711-8878, `email: denisecrispim2001@ yahoo.com
}

Manuscript received: 2 October 2020. Revision accepted: 5 November 2020.

\begin{abstract}
Ferreira NH, Ribeiro AB, Morais MD, Peixoto AM, Bernardino MA, Moreira MR, Soares ACF, Heleno VCG, Veneziani RCS, Tavares DC. 2020. Cytotoxic and genotoxic effects of the ent-kaurenoic acid and ent-kaurenoic acid-enriched Mikania glomerata extract in V79. Biofarmasi J Nat Prod Biochem 18: 1-4. The ent-kaurenoic acid-rich extract from Mikania glomerata Sprengel effectively inhibited the formation of Streptococcus mutans biofilm. Given the biological potential of this extract and its major component, the present study was carried out to evaluate the safety of the ent-kaurenoic acid-rich extract from Mikania glomerata Sprengel and entkaurenoic acid alone in an in the vitro test system. The results showed that the ent-kaurenoic acid-rich extract from Mikania glomerata Sprengel was cytotoxic at concentrations up to $40.0 \mu \mathrm{g} / \mathrm{mL}$. Genotoxic effects were observed in cell cultures treated with the highest concentrations tested of ent-kaurenoic acid-rich extract from Mikania glomerata Sprengel (10.0 and $15.0 \mu \mathrm{g} / \mathrm{mL})$ and $e n t$-kaurenoic acid alone $(2.5,5.0$ and $7.5 \mu \mathrm{g} / \mathrm{mL})$ when compared to the control group. Therefore, the ent-kaurenoic acid-rich extract from Mikania glomerata Sprengel demonstrated cytotoxicity and genotoxicity effects at the highest concentrations tested, while ent-kaurenoic acid showed to be genotoxic at the same concentrations present in the an ent-kaurenoic acid-rich extract from Mikania glomerata Sprengel in V79 cells. These results demonstrate that the ent-kaurenoic acid should be partly responsible for the genotoxicity of ent-kaurenoic acidrich extract from Mikania glomerata Sprengel.
\end{abstract}

Keywords: Clonogenic assay, cytotoxicity, ent-kaurenoic acid, genotoxicity, Mikania glomerata

\section{INTRODUCTION}

In a recent study, our research group described the entkaurenoic acid-rich extract from $M$. glomerata Sprengel $(\mathrm{KAMg})$ as a new proposal for antimicrobial products for oral care. The results presented by the authors showed that $\mathrm{KAMg}$ was effective in inhibiting the formation of Streptococcus mutans biofilm (Moreira et al., 2016). Given the biological potential of this extract and its major component (ent-kaurenoic acid - KA - Figure 1), the present study was carried out to evaluate the cytotoxic potential of KAMg through the clonogenic efficiency assay and the genotoxic potential of KAMg and KA in the V79 (Chinese hamster lung fibroblasts) cell line through the cytokinesis-block micronucleus assay.

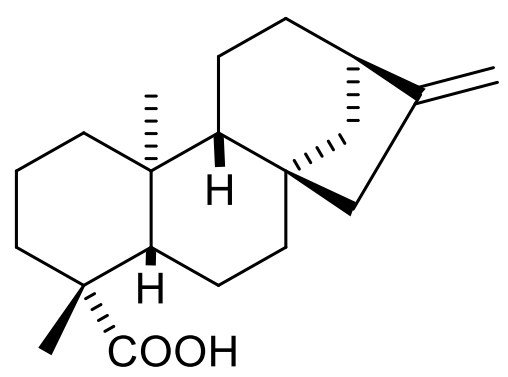

Figure 1. Chemical structure of ent-kaurenoic acid

\section{MATERIALS AND METHODS}

\section{Procedures}

Obtention of the ent-kaurenoic acid-rich M. glomerata extract and ent-kaurenoic acid

$\mathrm{KAMg}$ was prepared and characterized as described by Moreira et al. (2016). The KA content in the extract was determined after developing and validating a reverse-phase HPLC analytical method, which corresponded to about $48 \%$ of KA content in KAMg (Moreira et al., 2016). The KA samples used in this work were obtained from the leaves of $M$. glomerata, just as described by Soares et al. (2019).

\section{Cell line and culture conditions}

The Chinese hamster lung fibroblasts (V79 cell line) were employed for experimental assays. The cell line was maintained as monolayers in plastic culture flasks $(25 \mathrm{~cm} 2)$ in HAM-F10 plus DMEM (1:1; Sigma-Aldrich) culture medium supplemented with $10 \%$ fetal bovine serum (Nutricell), antibiotics $(0.01 \mathrm{mg} / \mathrm{mL}$ streptomycin and $0.005 \mathrm{mg} / \mathrm{mL}$ penicillin; Sigma-Aldrich), and $2.38 \mathrm{mg} / \mathrm{mL}$ HEPES (Sigma-Aldrich), at $37^{\circ} \mathrm{C}$ in a humidified $5 \% \mathrm{CO} 2$ atmosphere. The V79 cells were used from the $4^{\text {th }}$ until the $12^{\text {th }}$ passage. This cell line has an average cycle of $12 \mathrm{~h}$ in the experimental conditions described. 


\section{Cytotoxicity assessment}

The clonogenic efficiency assay was used to determine the cytotoxicity of KAMg. For this, cells were treated for 3 $\mathrm{h}$ with $\mathrm{KAMg}$ concentrations ranging from 0.3 to 160 $\mu \mathrm{g} / \mathrm{mL}$. Negative (no treatment), solvent (Methanol, $\mathrm{MeOH}, 0.4 \%$ ), and positive (methyl methanesulfonate, MMS, Sigma-Aldrich, $110 \mu \mathrm{g} / \mathrm{mL}$ ) controls were also included. Following, the cultures were trypsinized, and 300 cells were seeded per culture flask (three flasks per concentration). The experiments were carried out for 10 days. The culture medium was then removed, and the colonies were washed with PBS (phosphate-buffered saline), fixed (1:1:9 of methanol/acetic acid/distilled water), and stained with Giemsa (1:20 in phosphate buffer, $\mathrm{pH}$ 7.0) for 20 minutes. Individually stained colonies were counted, and the colony-surviving fraction was calculated as follows (adapted from Franken et al. 2006):

$$
\mathrm{SF}(\%)=(\mathrm{A} / \mathrm{B}) \times 100
$$

Where; $A$ corresponds to the number of colonies found in the corresponding treatments and $B$ to the number of colonies found in the negative control.

\section{Genotoxicity assessment}

The cytokinesis-block micronucleus assay was used to determine the genotoxicity of $\mathrm{KAMg}$ and $\mathrm{KA}$. The concentrations of KAMg were chosen based on the results of the clonogenic efficiency assay, using cytotoxicity as selection criteria, according to OECD 487 (2016). The concentrations of KA were chosen according to the content of $\mathrm{KA}$ in $\mathrm{KAMg}$, which corresponded to $48 \%$. To assess the genotoxicity, $1 \times 10^{6}$ cells were seeded in culture flasks, incubated for two cycles $(24 \mathrm{~h})$ in $5 \mathrm{~mL}$ of complete HAMF10/DMEM medium, washed with PBS, $\mathrm{pH} 7.4$, and then submitted to the treatment in serum-free medium for $3 \mathrm{~h}$ with $\operatorname{KAMg}(2.5,5.0,10.0$ and $15.0 \mu \mathrm{g} / \mathrm{mL})$ or $\mathrm{KA}(1.25$, 2.5, 5.0 and $7.5 \mu \mathrm{g} / \mathrm{mL}$ ). Negative control (no treatment), solvents $(\mathrm{MeOH}, 0.4 \%$ for $\mathrm{KAMg}$ and dimethylsulfoxide, DMSO, Sigma-Aldrich, 1\% for KA), and positive (MMS, $44 \mu \mathrm{g} / \mathrm{mL}$ ) controls were also included. At the end of this period, cells were washed twice with PBS. A fresh serumsupplemented medium containing $3 \mu \mathrm{g} / \mathrm{mL}$ cytochalasin-B (Sigma-Aldrich) was added, and the cells were incubated for an additional $17 \mathrm{~h}$. At harvest, the cells were trypsinized $(0.025 \%)$, and a hypotonic solution of $1 \%$ sodium citrate at $37^{\circ} \mathrm{C}$ was added. The cells were then fixed in methanol: acetic acid (3:1), and the slides were stained with $3 \%$ Giemsa for 5 minutes.

The criteria established by Fenech (2000) were used to analyze micronuclei and binucleated cells. A total of 3000 binucleated cells were scored per treatment, corresponding to 1000 cells/treatment/repetition. For the evaluation of cytotoxicity of the treatments was analyzed 1500 cells analyzed per treatment, for a total of 500 cells per repetition, and the nuclear division index (NDI) was calculated. Cells with well-preserved cytoplasm containing 1-4 nuclei were scored. The NDI was calculated using the following formula (Kirsch-Volders et al. 2004):

$$
\mathrm{NDI}=(\mathrm{M} 1+2 \times \mathrm{M} 2+3 \times \mathrm{M} 3+4 \times \mathrm{M} 4) / \mathrm{N}
$$

Where; M1-M4 is the number of cells with 1, 2, 3, and 4 nuclei, respectively, and $N$ is the total number of viable cells.

Additionally, the cytotoxicity index (CI) of KAMg and KA was calculated as described by Kirsch-Volders et al. (2004):

$$
\mathrm{CI}=100-100 \times[(\text { NDIt }-1) /(\text { NDIc }-1)]
$$

Where; NDIt is the NDI value found for the different treatments, and NDIC is the NDI value of the negative control.

\section{Data analysis}

Data were statistically analyzed by analysis of variance (ANOVA) for completely randomized experiments; the statistical $\mathrm{F}$ and its respective "p-value" were calculated. The Tukey method compared the treatment means in cases where $p<0.05$, and the minimum significant difference was calculated for $\alpha=0.05$. All statistical analyses were performed using the GraphPad Prism 5.0 program (GraphPad Sofware, San Diego, CA, USA).

\section{RESULTS AND DISCUSSION}

\section{Cytotoxicity assessment}

Dose-dependent changes in the viability of $\mathrm{KAMg}$ treated cells were evaluated using the clonogenic efficiency assay. Each survival curve represents the mean of three independent experiments, and the bars indicate the standard error of the mean (Figure 2). Cultures treated with KAMg concentrations above $20.0 \mu \mathrm{g} / \mathrm{mL}$ showed significant reductions in cell viability compared to the control cultures, indicating a cytotoxic effect. Therefore, $\mathrm{KAMg}$ concentrations of $2.5,5.0,10.0$, and $15.0 \mu \mathrm{g} / \mathrm{mL}$ were chosen for further analysis in the genotoxic assay.

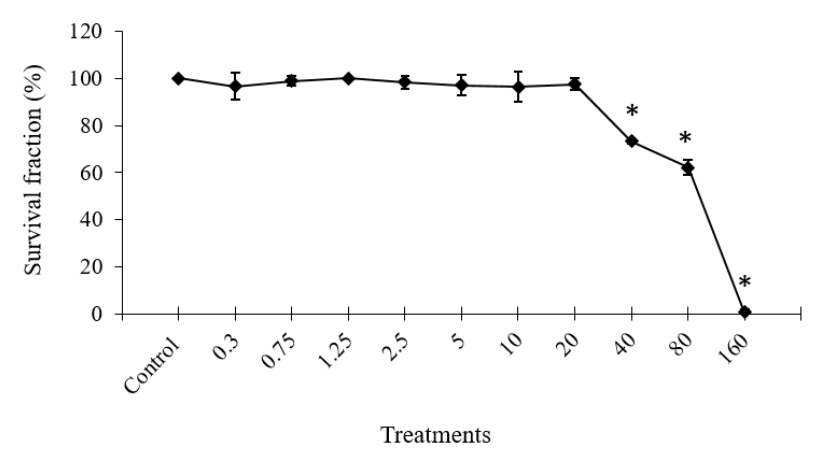

Figure 2. Cell survival means percentages obtained after exposure of V79 cells to ent-kaurenoic acid-rich extract from $M$. glomerata Sprengel (KAMg) concentrations ranging from 0.3 to $160.0 \mu \mathrm{g} / \mathrm{mL}$. MeOH: methanol (0.4\%); MMS: methyl methanesulfonate $(110 \mu \mathrm{g} / \mathrm{mL})$. *Significantly different from the control group $(P<0.05)$. 
Table 1. Mean frequencies of micronuclei (MN), nuclear division index (NDI), and cytotoxicity index observed in V79 cell cultures treated with different concentrations of ent-kaurenoic acidrich extract from M. glomerata Sprengel, and their respective controls

\begin{tabular}{|c|c|c|c|}
\hline $\begin{array}{l}\text { Treatment } \\
(\mu \mathrm{g} / \mathrm{mL})\end{array}$ & $\begin{array}{c}\text { MN } \\
\text { frequency }\end{array}$ & Mean \pm SD & $\begin{array}{c}\text { Cytotoxicity } \\
\text { index } \\
(\%)\end{array}$ \\
\hline Control & $5.33 \pm 1.15$ & $1.74 \pm 0.04$ & - \\
\hline $\mathrm{MeOH}$ & $4.33 \pm 1.15$ & $1.69 \pm 0.08$ & 6.76 \\
\hline 2.5 & $9.00 \pm 2.00$ & $1.66 \pm 0.09$ & 10.82 \\
\hline 5.0 & $11.33 \pm 5.86$ & $1.63 \pm 0.10$ & 14.87 \\
\hline 10.0 & $16.00 \pm 2.65^{\mathrm{c}}$ & $1.60 \pm 0.05$ & 18.92 \\
\hline 15.0 & $17.33 \pm 2.52^{\mathrm{c}}$ & $1.35 \pm 0.03^{\mathrm{c}}$ & 52.71 \\
\hline MMS & $62.33 \pm 1.53^{\mathrm{c}}$ & $1.60 \pm 0.07$ & 18.92 \\
\hline
\end{tabular}

Note: MeOH: methanol (0.4\%); MMS: methyl methanesulfonate (44 $\mu \mathrm{g} / \mathrm{mL})$. ${ }^{\text {a A }}$ total of 3000 binucleated cells was scored per treatment, corresponding to 1000 cells/treatment/repetition for the determination of micronucleus frequency. ${ }^{\mathrm{b}} \mathrm{A}$ total of 1500 cells was analyzed per treatment group, corresponding to 500 cells/treatment/repetition for calculation of NDI. 'Significantly different from the control group $(P<0.05)$.

\section{Genotoxicity assessment}

Table 1 shows the mean frequencies of binucleated cells with micronuclei and the mean standard deviation after exposure to KAMg. There was no significant difference in micronuclei induction observed between cultures treated with KAMg concentrations of 2.5 and 5.0 $\mu \mathrm{g} / \mathrm{mL}$ and the control group. However, a significant micronuclei frequency increase was observed in cultures treated with 10.0 and $15.0 \mu \mathrm{g} / \mathrm{mL}$ of KAMg compared to the control, demonstrating genotoxicity for these concentrations. In relation to NDI, the cultures treated with the highest concentration of KAMg tested $(15.0 \mu \mathrm{g} / \mathrm{mL})$ showed significantly lower indexes when compared to the cultures of the control group, with a cytotoxicity index equal to $52.71 \%$. In this way, KA (in a percentage corresponding to KAMg concentrations) treatment groups were included to assess whether the genotoxic effect of $\mathrm{KAMg}$ at the highest concentrations was due to the presence of KA.

Table 2 shows the mean frequencies of binucleated cells with micronuclei and NDI after exposure to KA. The lowest tested concentration of KA did not significantly increase the micronuclei frequency compared to the control group. On the other hand, the results showed a significant increase in micronuclei frequency at concentrations of 2.5 , 5.0 , and $7.5 \mu \mathrm{g} / \mathrm{mL}$, compared to the control group, demonstrating genotoxic activity. The results of NDI (nuclear division index) showed no significant differences for any KA concentration compared to the control group, revealing the absence of cytotoxicity.

\section{Discussion}

The present study aimed to investigate the cytotoxic and genotoxic potential of KAMg in V79 cells. The results demonstrated cytotoxic and genotoxic effects of KAMg at the highest concentrations tested through the clonogenic efficiency assay (above $20 \mathrm{ug} / \mathrm{mL}$ ) and the micronucleus
Table 2. Mean frequencies of micronuclei $(\mathrm{MN})$ and nuclear division index (NDI) were observed in V79 cell cultures treated with different concentrations of kaurenoic acid and their respective controls.

\begin{tabular}{lcc}
\hline Treatments & MN frequency & NDI $^{\mathbf{b}}$ \\
\cline { 2 - 3 }$(\boldsymbol{\mu g} / \mathbf{m L})$ & Mean \pm SD & Mean \pm SD \\
\hline Control & $6.67 \pm 2.08$ & $1.66 \pm 0.02$ \\
DMSO & $6.33 \pm 1.15$ & $1.70 \pm 0.12$ \\
1.25 & $14.67 \pm 2.08$ & $1.64 \pm 0.06$ \\
2.5 & $20.00 \pm 5.29^{\mathrm{c}}$ & $1.65 \pm 0.09$ \\
5.0 & $17.67 \pm 2.31^{\mathrm{c}}$ & $1.76 \pm 0.14$ \\
7.5 & $17.67 \pm 4.04^{\mathrm{c}}$ & $1.72 \pm 0.13$ \\
MMS & $62.33 \pm 1.53^{\mathrm{c}}$ & $1.68 \pm 0.08$ \\
\hline
\end{tabular}

Note: DMSO: dimethylsulfoxide (1\%); MMS: methyl

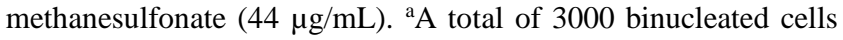
was scored per treatment, corresponding to 1000 cells/treatment/repetition for micronucleus frequency determination. ${ }^{\mathrm{b}} \mathrm{A}$ total of 1500 cells was analyzed per treatment group, corresponding to 500 cells/treatment/repetition for NDI calculation. 'Significantly different from the control group $(P<0.05)$.

assay $(10$ and $15 \mathrm{ug} / \mathrm{mL})$, respectively. In order to investigate the influence of KA on the genotoxicity of the extract, the genotoxic potential of this diterpene was evaluated in the concentrations present in KAMg. Except for the lowest KA tested concentration, all others revealed genotoxic effects. These results demonstrate that KA should be responsible, at least in part, for the genotoxicity of KAMg.

Some studies have already demonstrated the genotoxic potential of M. glomerata extract and KA. Dalla Nora et al. (2010) observed the genotoxic and antiproliferative effects of M. glomerata leaves extract on Allium cepa cells. The genotoxicity of the $M$. glomerata leaves extract was also reported by Costa et al. (2008) using murine hepatoma cells (HTC).

Cavalcanti et al. (2006) demonstrated the genotoxic effect of KA at concentrations of 30 and $60 \mu \mathrm{g} / \mathrm{mL}$ in V79 cell lines using the comet and micronucleus assays. However, Cano et al. (2017) investigated the genotoxicity of KA in the CHO-K1 (Chinese hamster ovary) cell line using the micronucleus assay, and this diterpene showed no genotoxicity at concentrations ranging from 7.36 to 30.25 $\mu \mathrm{g} / \mathrm{mL}$. O'Donovan (1990) and Erexson et al. (2001) reported that $\mathrm{CHO}$ and $\mathrm{V79}$ cell lines vary significantly in their ability to metabolize endotoxins. This difference in cellular metabolic capacity may explain the results difference obtained in relation to the genotoxicity of KA.

In relation to the genotoxicity of $\mathrm{KAMg}$, it is important to note that extracts are complex mixtures of biologically active substances that may act synergistically or antagonistically. All these effects may lead to attenuation or accentuation of genotoxic and or cytotoxic effects caused by some specific substance. The enrichment of $M$. glomerata extract with KA may have contributed to the genotoxicity of the $\mathrm{KAMg}$, since $\mathrm{KA}$ showed to be genotoxic at the same concentrations present in the enriched extract. 
Cavalcanti et al. (2010) demonstrated that the genotoxic and mutagenic properties of KA are due to clastogenic damage, probably derived from DNA double-strand breaks and/or inhibition of topoisomerase I. In addition, the authors confirmed that the exocyclic double bond (C16) in the chemical structure of KA is an important element in its genotoxicity and mutagenicity.

Despite the genotoxicity of the extract observed in the in vitro test system, $\mathrm{KAMg}$ did not show genotoxic or cytotoxic activity in Swiss mice bone marrow by the micronucleus test (Moreira et al. 2016). Factors such as metabolism, pharmacokinetics, and pharmacodynamics alter compounds' distribution and concentration in more complex organisms than cellular units (Singulani et al., 2018).

The oral bioavailability of numerous drugs is greatly reduced before reaching systemic circulation (Kuppens et al. 2005). The first pass effect reduces the concentration of a drug to such an extent that only a small amount of active drug emerges from the liver to the systemic circulation and the target tissue, thus impacting its biological effect on in vivo systems (Sousa \& Bernkop-Schnürch 2014).

Jiang et al. (2019) carried out the pharmacokinetic analysis of KA after oral administration of 10, 20, and 40 $\mathrm{mg} / \mathrm{kg}$ in rats to $36 \mathrm{~h}$ after the treatment. The pharmacokinetic parameters indicated that KA was widely distributed in body tissues with high $\mathrm{Vz} / \mathrm{F}$ values (apparent volume of distribution during terminal phase after nonintravenous administration) and experienced slow in vivo elimination after oral administration with terminal phase half-life $\left(\mathrm{t}^{1 / 2 \mathrm{z}}\right)>10 \mathrm{~h}$ values for all doses.

The absence of genotoxicity of KAMg in in vivo test system may be related to the high liposolubility of KA. The high value in the partition coefficient of KA (5.4) may influence a higher concentration in adipose tissues and a slow concentration released into the bloodstream that exerts genotoxic effects on the bone marrow.

Under the experimental conditions used, $\mathrm{KAMg}$ demonstrated cytotoxicity as well as genotoxicity at the highest concentrations tested. At the same time, KA showed to be genotoxic at the same concentrations present in KAMg in V79 cells. These results demonstrate that KA should be responsible, at least in part, for genotoxicity KAMg.

\section{ACKNOWLEDGEMENTS}

This work was supported by the São Paulo Research Foundation (FAPESP, Brazil; grant no. 2016/24269-7) and by Coordination for the Improvement of Higher Education Personnel (CAPES, Brazil). The authors are grateful to the
National Council for Scientific and Technological Development (CNPq, Brazil) for the fellowships granted.

\section{REFERENCES}

Cano BL, Moreira MR, Goulart MO, Gonçalves NS, Veneziani RCS, Bastos JK, Santos RA. 2017. Comparative study of the cytotoxicity and genotoxicity of kaurenoic acid and its semi-synthetic derivatives methoxy kaurenoic acid and kaurenol in CHO-K1 cells. Food Chem Toxicol 102: 102-108.

Cavalcanti BC, Costa-Lotufo LV, Moraes MO, Burbano RR, Silveira ER, Cunha KMA, Pessoa C. 2006. Genotoxicity evaluation of kaurenoic acid, a bioactive diterpenoid present in Copaiba oil. Food Chem Toxicol 44: 388-392.

Cavalcanti BC, Ferreira JRO, Moura DJ, Rosa RM, Furtado GV, Burbano RR, Henriquees JAP. Structure-mutagenicity relationship of kaurenoic acid from Xylopia sericeae (Annonaceae). Mutat Res 701: 153-163.

Costa R, Diniz A, Mantovani MS, Jordão BQ. 2008. In vitro study of mutagenic potential of Bidens pilosa Linné and Mikania glomerata Sprengel using the comet and micronucleus assays. J Ethnopharmacol 118: 86-93.

Dalla Nora G, Pastori T, Laughinghouse IV D, Canto-Dorow D, Scotti T. Tedesco SB. 2010. Antiproliferative and genotoxic effects of Mikania glomerata (Asteraceae). Biocell 34: 95-101.

Erexson GL, Periago MV, Spicer CS. 2001. Differential sensitivity of Chinese hamster V79 and Chinese hamster ovary (CHO) cells in the in vitro micronucleus screening assay. Mutat Res 495: 75-80.

Fenech M. 2000. The in vitro micronucleus technique. Mutat Res 455(12): 81-95.

Franken NA, Rodermond HM, Stap L, Haveman I, van Bree C. 2006. Clonogenic assay of cells in vitro. Nat Protoc 1: 2315-2319.

Jiang X, Shen Y, Wang H, Wang C, Ye X, Xiang Z. 2019. Determination of kaurenoic acid in rat plasma using UPLC-MS/MS and its application to a pharmacokinetic study. J Pharm Biomed Anal 164: 27-31.

Kirsch-Volders M, Sofuni T, Aardema M, Albertino S, Eastmond D, Fenech M, Norppa H. 2004. Corrigendum to "Report from the in vitro micronucleus assay working group". Mutat Res 1: 97-100.

Kuppens IE, Breedveld P, Beijnen JH, Schellens JHM. 2005. Modulation of oral drug bioavailability: from preclinical mechanism to therapeutic application. Cancer Invest 23: 443-464.

Moreira MR, Souza AB, Soares S, Bianchi TC, de Souza Eugênio D, Lemes DC, Matins CHG, da Silva Moraes T, Tavares DC, Ferreira NH, Ambrosio SR, Veneziani RCS. 2016. ent-Kaurenoic acid-rich extract from Mikania glomerata: In vitro activity against bacteria responsible for dental caries. Fitoterapia 112: 211-216.

O’Donovan MR. 1990. 1, 8-Dinitropyrene: comparative mutagenicity in Chinese hamster V79 and CHO cells. Mutagenesis 5: 275-278.

OECD Test. 2016. 487: In vitro mammalian cell micronucleus test. OECD Guidelines for the Testing of Chemicals, Section 4: 1-26.

Singulani JL, Pedroso RS, Ribeiro AB, Nicolella HD, Freitas KS, Damasceno JL, Vieira TM, Crotti AE, Tavares DC, Martins CH, Mendes-Giannini MJ, Pires RH. 2018. Geraniol and linalool anticandidal activity, genotoxic potential and embryotoxic effect on zebrafish. Future Microbiol 13: 1637-164.

Soares ACF, Matos PM, Dias HJ, Aguiar GP, Santos ES, Martins CHG, Veneziani RCS, Ambrósio SR, Heleno VCG. 2019. Variability of the antibacterial potential among analogue diterpenes against Grampositive bacteria: considerations on the structure-activity relationship. Can J Chem 97: 568-575.

Sousa IP, Bernkop-Schnürch A. 2014. Pre-systemic metabolism of orally administered drugs and strategies to overcome it. J Control Release 192: 301-309. 